We thank Dr J. Sikorski of the Textile Department, University of Leeds, for access to the Stereoscan microscope and for his support, and Mr T. Buckley of the same department for his practical assistance.

I. J. Smalley

J. G. CABRERA

Department of Civil Engineering,

University of Leeds,

Leeds.

Received February 24, 1969.

${ }^{1}$ Lambe, T. W., Proc. Amer. Soc. Civ. Enı., 79, No. 315 (1953)

${ }^{2}$ Rosenqvist, I. T., J. Soil Mech. and Found. Div., Amer. Soc. Civ. Eng., 85, No. SM2, 31 (1959).

${ }^{3}$ Sloane, R. L., and Kell, T. R., Clays and Clay Min., Proc. Fourteenth Nat. Conf., 289 , (1966).

- Kirkham, D., De Boodt, M. F., and De Leenheer, L., Soil Sci., 87, 141 (1959).

${ }^{-}$Smart, P., Clays and Clay Min., Proc. Fifteenth Nat. Conf., 241 (1967).

' Schofield, K. K., and Samson, H. R., Disc. Farad. Soc., 18, 135 (1954).

\section{Determination of the Firing Temperature of Ancient Ceramics by Measurement of Thermal Expansion}

THE thermal expansion method for determining firing temperatures ${ }^{1-3}$ is based on the assumption that, when clays are fired, shrinkage occurs as a result of various sintering processes such as vitrification. Consequently when a clay ceramic is heated up from room temperature (see Fig. 1) it typically exhibits a reversible expansion, characteristic of its mineralogical composition, until temperatures comparable with the original firing temperature are reached. With continued increase in temperature the ceramic begins to contract because superimposed on the reversible expansion there is an irreversible shrinkage associated with resumption of sintering (that is, the firing of the ceramic is being continued beyond the point reached during the original firing). The temperature $\left(T_{a}\right)$ at which a net shrinkage is first observed should therefore provide an indication of the original firing temperature $\left(T_{e}\right)$ of the ceramic.

Firing temperature determinations were undertaken on a selection of ceramies with a wide range of provenance and age (Table 1). Specimens $(2.5 \times 1.0 \times 1.0 \mathrm{~cm})$ were cut from the pottery sherds and the shrinkage temperature, $T_{a}$, was measured using extension rod dilatometers ${ }^{3,4}$. The specimen was then refired for $1 \mathrm{~h}$ at temperature,

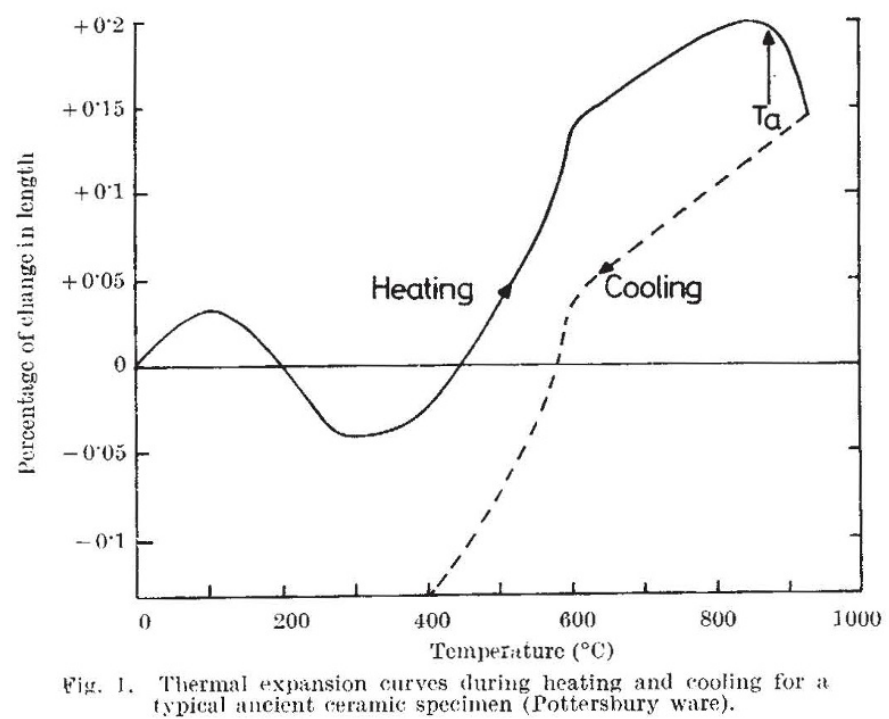

Table 1. FIRING TEMPRRATURE OF ANCLENT CERAMCS

\begin{tabular}{|c|c|c|c|}
\hline \multirow[b]{2}{*}{ Provenance } & \multicolumn{2}{|c|}{ Archaeological data } & \multirow{2}{*}{$\begin{array}{c}\text { Firing tem- } \\
\text { perature }\left(T_{e}{ }^{\circ} \mathrm{C}\right)\end{array}$} \\
\hline & Period/age & Type & \\
\hline $\begin{array}{l}\text { Turkey } \\
\text { Irag }\end{array}$ & $\begin{array}{l}\text { c. } 5000 \mathrm{BC} \\
\text { c. } 4500 \mathrm{BC}\end{array}$ & Halaf ware & $750-820$ \\
\hline Iracl & $\begin{array}{l}\text { c. } 4500 \mathrm{BC} \\
\text { c. } 3500 \mathrm{BC}\end{array}$ & $\begin{array}{l}\text { Halaf ware } \\
\text { 'Ubaid ware }\end{array}$ & $\begin{array}{r}970-1,050 \dagger \\
1.140-1,180\end{array}$ \\
\hline Cyprus & c. $3000 \mathrm{BC}$ & & $\begin{array}{r}1,1+0-1,180 \\
500-700\end{array}$ \\
\hline Cyprus & c. $1300 \mathrm{BC}$ & Mycenaean ware & $940-1,000 \div$ \\
\hline Cyprus & c. $1300 \mathrm{BC}$ & Mycenaean copy & $1,030-1,070 \dagger$ \\
\hline $\begin{array}{l}\text { Turkey } \\
\text { Nigeria }\end{array}$ & c. $500 \mathrm{BC}$ & Greek Attic ware & $1,000-1,100$ \\
\hline $\begin{array}{l}\text { Nigeria } \\
\text { China }\end{array}$ & & Clay figurine & $<<500$ \\
\hline $\begin{array}{l}\text { China } \\
\text { China }\end{array}$ & c. $1100 \mathrm{AD}$ & Porcelain & $1,070-1,140^{*}$ \\
\hline China & c. $1100 \mathrm{AD}$ & Celadon & $1,070-1,190^{*}$ \\
\hline England & c. $1700 \mathrm{AD}$ & $\begin{array}{l}\text { Porcelain } \\
\text { Calcite gritted ware }\end{array}$ & $960-1,050^{*}$ \\
\hline England & $\begin{array}{l}\text { Tron Age } \\
\text { Roman }\end{array}$ & $\begin{array}{l}\text { Calcite gritted ware } \\
\text { Black burnished ware }\end{array}$ & $\begin{array}{r}500-700 \\
<800\end{array}$ \\
\hline Fngland & Roman & Grey ware & $900-960+$ \\
\hline England & Roman & Colour coated ware & $910-980$ \\
\hline Fingland & Roman & Mortarium & $930-990$ \\
\hline England & Roman & Samian ware & $1,100-1,150$ \\
\hline England & Saxon & & $500-700$ \\
\hline England & Saxon & Thetford ware & $960 \dagger$ \\
\hline England & Mediacval & Laverstock ware & $750-$ \\
\hline England & Mediaeval & Cowick ware & $940-990 \dagger$ \\
\hline England & c. $1650 \mathrm{AD}$ & Pottersbury ware & $910-950$ \\
\hline
\end{tabular}

$T_{e}^{\prime}$, and the new shrinkage temperature, $T_{a}^{\prime}$, was measured.

The values obtained for $T_{a}$ ranged from $620^{\circ}-1,230^{\circ} \mathrm{C}$. When $T_{a}$ was less than $700^{\circ} \mathrm{C}$, the thermal expansion data provided no precise information on the firing temperature and it was only possible to suggest that $T_{e}$ was either less than $500^{\circ} \mathrm{C}$ or in the $500-700^{\circ} \mathrm{C}$ range, depending on whether or not hydrated clay minerals were present in the ceramies ${ }^{5}$. Similarly when the ceramic contained calcite, $T_{e}$ was probably less than $800^{\circ} \mathrm{C}$; the value for $T_{a}$ being invalid because this mineral produced a complex pattern of expansion and contraction. For the remainder of the ceramics, $T_{e}$ was calculated using the relationship

$$
\left(T_{e}-T_{a}\right)=\left(T_{e}^{\prime}-T_{a}{ }^{\prime}\right)
$$

Measurements on clay specimens, prefired at known temperatures, indicated that this relationship was valid for a wide range of firing temperatures provided vitrification occurred during the original firing and $T_{e}^{\prime}$ was selected such that $\left(T_{e}^{\prime}-T_{e}\right)$ equalled approximately $20-30^{\circ} \mathrm{C}$. Even in these circumstances, however, the value obtained for $T_{e}$ may be too high as a result of bloating caused by the expansion of gases trapped in the liquid phase of the clay body. Alternatively $T_{e}$ may be too low because shrinkage, resulting from the pressure excrted on the specimen by the dilatometer components, can occur when the viscosity of the liquid phase decreases at high temperatures.

The values estimated for $T_{e}$ (Table 1) show that firing temperatures ranging from $500^{\circ} 1,200^{\circ} \mathrm{C}$ were used in the manufacture of ancient ceramies and that low or high firing temperatures were not confined to particular periods or parts of the world. The data provide valuable information on the performance of ancient pottery kilns and on the technological eapability of the potters. A knowledge of the firing temperature can also be valuable in other scientific investigations of ancient eeramics and kilns such as thermoluminescent and magnetic dating.

I thank Professor J. P. Roberts for helpful discussions on this problem. This work was supported by the Science Research Council and an ICI research fellowship.

\section{S. TiTE*}

Department of Ceramics,

Houldsworth School of Applied Science,

University of Leeds.

Received January 9, 1969

* Present address: Department of Physies, Iniversity of Essex, Colchester.

1 Kiefer, ('h., Bull. Soc. Frane. Ceram., 30, 3 (1956); 31, 17 (1956).

2 'Terrisse, J. R., Rei Cretariae Romanae Fautorum, 2, 63 (1959).

${ }^{3}$ Roberts, J. P., Arehueometry, 6, 21 (1963).

${ }^{4}$ Baudran, A., Bull. Soc. Frane. Ceram., 27. 33 (1955).

serinet, G., T'rans. Senenth Intern. Cerum. Cong., London. 3i1 (196(1). 